\author{
Joanna Domańska \\ Sczecińska Szkoła Wyższa Collegium Balticum \\ Instytut Pedagogiki
}

\title{
Dobroczynność względem sierot na ziemiach polskich do 1918 roku
}

\author{
Abstract. Joanna Domańska, Charity Care of Orphaned Children in the Polish Territories Until \\ 1918
}

Since the baptism of Poland up to 1918, the social care of orphans was diversified. Until the annexations, the care of parentless children in the Polish territories had been environmental and stemmed from voluntary and charitable actions taken up mostly by the Church. The creation of children wards in hospitals and shelters, and the establishment of children's households in Warsaw as a result of father G. Baudounin's initiative, might be considered as prototype actions in the complete institutional care of orphaned children.

However, during the time of annexations, the situation of orphans became significantly diversified because it depended on the invaders' policy and the citizens' activity. Thus, on the one hand, it was created by the occupying country, on the other, it was shaped by tradition. In the territories of each of the conquerors there were periods of liberalization of law, which rendered it possible, at least to some degree, to follow Polish concepts. These were mostly based on philanthropy, charity religious groups, associations and individuals.

It needs to be stated that at the beginning of the 21 st century, in all of the partitioned territories, the orphanages were governed by obsolete regulations although tried out in other countries.

In each of the annexed parts of Poland, the educational and caring actions stemmed from the acquired legislative system. Under the Austrian occupation it was the commune that had the duty of taking care of the parentless children as it was stated in the act passed on 3rd December 1863. In the Prussian part of Poland, the commune's duty of taking care of the orphans was stated in the act passed in July 1870. It is worth mentioning that the legislative in Prussia was very similar to the Austrian one. The only difference between them was their effectiveness - it was far more efficient in the Prussian province.

Under the Russian invasion the regulations concerning the orphanages were quite different. Since the resolution from 1817, the public care of orphans relied on the good will of the society. It was not until the ruling from 1870 that the city councils of public philanthropy, supervising such institutions, were brought to life. 
At the turn of the 19th century in Poland, especially among social and educational activists, the problem of children's care became more popular. The necessity of providing care through social actions based on the law was discerned.

During World War I, the problem of orphanhood achieved a new dimension, the so-called war orphanhood. It was not effectively taken care of until the end of the war.

Keywords: Charity Care of Children, Poland, 20th Century

$\mathrm{Na}$ ziemiach polskich działalność dobroczynna względem sierot rozwijała się po przyjęciu chrztu przez Polskę. Organizowana była przez zakony, zwłaszcza te, które w swej regule miały obowiązek opieki nad ubogimi, m.in. przez: zakon Benedyktynów, zakon św. Jana Jerozolimskiego, zwany maltańskim i zakon Kanoników Regularnych Szpitalnych Świętego Ducha ${ }^{1}$. Inne zakony zajmujące się pracą charytatywną o znaczeniu lokalnym to: mercedariusze, szpitalnicy św. Antoniego, bracia św. Jakuba ${ }^{2}$.

Przy klasztorach zakonu maltańskiego w Poznaniu i Kaliszu istniały przytułki. Natomiast przy zakonach Świętego Ducha zakładano szpitale ${ }^{3}$, które podobnie jak i inne nie były miejscem leczenia chorych (z nielicznymi wyjątkami), lecz spełniały funkcję przytułku dla ubogich i dzieci porzuconych ${ }^{4}$. Najstarsze szpitale polskie ${ }^{5}$, o których wiadomo, powstały w XII w. ${ }^{6}$ Największe jednak znaczenie dla rozwoju szpitalnictwa w Polsce miał zakon kanoników regularnych Świętego Ducha 7 . Dobrze zorganizowaną opieką nad dziećmi porzuconymi charakteryzowały się szpitale w Krakowie, Kaliszu, Sandomierzu, Sławkowie i założony w XIV w. szpital w Stawiszynie. Były to jedyne na ziemiach polskich placówki dobroczynne, specjalizujące się w opiece nad podrzutkami ${ }^{8}$.

Funkcjonowanie polskich szpitali prowadzonych przez Kanoników Regularnych Świętego Ducha było na ogół podobne do systemu wypracowanego w szpitalu Świętego Ducha w Rzymie, z tym, że np. w szpitalu w Krakowie „oprócz chorych, ubogich i podrzutków, przyjmowano dodatkowo kobiety ciężarne oraz sieroty, czego nie czyniono w szpitalu rzymskim"9.

\footnotetext{
${ }^{1}$ K. Kowalewski, Opieka społeczna. (Dobroczynność publiczna), Wyd. s. n., Warszawa 1918, s. $12-13$.

${ }^{2}$ K. Górski, Zarys dziejów pracy charytatywnej Kościoła. Od czasów najdawniejszych do drugiej wojny światowej, „Studia Pelplińskie” T. XVII, Pelplin 1986, s. 215.

3 Ibidem, s. 214.

${ }^{4}$ Z. Góralski, Działalność charytatywna w Polsce przedrozbiorowej, PWN, Warszawa - Kraków 1973, s. $23-27$.

5 W 1108 r. Piotr Włast ufundował na Górze Sobótce szpital i oddał go w opiekę Kanonikom Regularnym św. Augustyna ; w 1152 r. arcybiskup gnieźnieński Janisław ufundował w Jędrzejowie szpital i klasztor Cystersów ; 1170 r. Mieszko Stary ufundował w Poznaniu szpital, który oddał w opiekę braciom św. Jana Jerozolimskiego.

${ }^{6}$ W. Męczkowski, Prowizorowie szpitalni w dawnej Polsce przedrozbiorowej. Przyczynek do dziejów magistratury naszej, „Przegląd Historyczny” 1907, t. V, z. 1, s. 9.

${ }^{7}$ Cz. Kępski, Towarzystwa dobroczynności w Królestwie Polskim (1815-1914), Lublin 1993, s. 23.

${ }^{8}$ M. Surdacki, Losy dzieci porzuconych $w$ społeczeństwie europejskim do XX wieku, w: Dziecko $w$ rodzinie i społeczeństwie. Dzieje nowożytne, red. K. Jakubiak, W. Jamrożek, Bydgoszcz 2002, s. 155-156.

9 Ibidem, s. 156.
} 
W szpitalu krakowskim dzieci do siódmego roku życia (niezależnie od płci) wychowywały siostry duchaczki. Powyżej tego wieku dziewczęta do okresu pełnoletności wychowywane były w szpitalu, następnie mogły wyjść za mąż lub wstąpić do zakonu. Natomiast chłopcy pozostawali pod opieką braci zakonnych oraz kształcili się w przyszpitalnej szkole. Na podkreślenie zasługuje fakt, że podrzutki spoza związków małżeńskich dzięki przebywaniu w szpitalu otrzymywały status prawnego pochodze$\operatorname{nia}^{10}$.

Szpital krakowski był dużą, dobrze zorganizowaną placówką. Do przyjmowania podrzutków wykorzystano tzw. metodę z kołem. Koło, to owalna, obracająca się na osi szafka umieszczona w oknie. Po włożeniu dziecka do tej szafki na zewnątrz budynku, wystarczyło ją popchnąć, aby niemowlę znalazło się w środku domu. O porzuconym dziecku matki zawiadamiały dzwonkiem, po czym oddalały się niepoznane ${ }^{11}$.

Szpital krakowski dzielił się na część żeńską i męską. Przełożonym szpitala był przełożony klasztoru, wybierany na okres trzech lat. Oddziałem kobiecym zarządzała zakonnica ze zgromadzenia żeńskiego Świętego Ducha. Zatrudniano także spowiednika, gospodarza, lekarza, pasterza bydła, pomoc kuchenną i praczkę. Największy procent podopiecznych stanowiły podrzutki. Na podstawie metrykalnej księgi chrztów stwierdzono, że rocznie przyjmowano ich od 18 do 53. Dzieci wątłe oddawano za opłatą rodzinom wiejskim, gdzie przebywały do 5 lub 6 roku życia, po czym wracały do zakładu. Śmiertelność w tymże zakładzie była bardzo duża ${ }^{12}$, głównie z powodu złych warunków sanitarno-higienicznych, chorób zakaźnych, wad i chorób wrodzonych ${ }^{13}$.

Jedyny zachowany opis dotyczący budynku Szpitala Świętego Ducha w Krakowie, pochodzi dopiero z 1738 r. Dowiadujemy się z niego, że był to obiekt piętrowy, zbudowany w kształcie trapezu. W środku u zbiegu skrzydeł stał kościół. Podopieczni przebywali w pomieszczeniach na piętrze. Wchodziło się tam z sieni od bramy wejściowej, skąd prowadziły schody na piętro. Nad schodami był dzwonek, zapewne zawiadamiający o podrzuconym dziecku. Na piętrze przechodziło się do sionki, a następnie przez pustą izbę do sali sierot, w której były cztery ławy, sześć łóżek i dwadzieścia kolebek. Z tego miejsca prowadziło wejście schodami na strych i do izby mamek. W mieszkaniu mamek stało osiem dużych łóżek, sześć kolebek, wózek dla dzieci, dwie skrzynie, szafa, dwa stoły ${ }^{14}$.

Do XV w. opiekę nad sierotami, podrzutkami, chorymi i wdowami pełniły też diakonise. Były to swego rodzaju wolontariuszki, które zwykle po 40. roku życia przyjmowały śluby zobowiązujące do życia bezżennego ${ }^{15}$.

10 Ibidem, s. 159

11 Źródła do pedagogiki opiekuńczej, red. I. Lepalczyk, s. 12.

12 L. Wacholz, Szpitale krakowskie 1222-1922, Ossolineum, Kraków 1921, s. 6-15.

${ }_{13}$ M. Surdacki, op. cit., s. 158.

${ }^{14}$ K. Antosiewicz, Opieka nad dziećmi w Zakonie Św,. Ducha $w$ Krakowie, w: Z badań nad dziejami zakonów i stosunków wyznaniowych na ziemiach polskich, red. E. Wiśniowski, Wyd. TN KUL, Lublin 1984, s. 52 .

15 J. S. Pelczar, Zarys dziejów miłosierdzia w Kościele Katolickim, Wyd. s.n., Kraków 1916, s. 32. 
Pieniądze na rzecz sierot zapewniał Kościół. W zwyczaju tamtej epoki były regularne kollekty i dziesięciny dla ubogich. Konstytucje Apostolskie żądały dziesięcin ze wszystkiego, co się posiadało, dotyczyły one produktów żywnościowych, sukna i pieniędzy ${ }^{16}$.

Pod koniec XV w. dochody przeznaczone na szpitale uległy uszczupleniu, zmalała ofiarność na cele charytatywne. Sytuacja ta była konsekwencją wydanego przez Jana Olbrachta w 1496 r. prawa dotyczącego ubogich ${ }^{17}$.

W końcowym okresie średniowiecza, obok szpitali, pracą na rzecz sierot zajmowały się także bractwa. Były to świeckie korporacje religijne, ściśle związane z Kościołem, który powołał je do życia i określił ich miejsce w społeczności wiernych ${ }^{18}$. Charakterystyczne było gęste ich rozmieszczenie, w każdej parafii bowiem istniał jeden związek bracki ${ }^{19}$. Stopniowo pojawiały się też w mniejszych miastach i wsiach. Bractwa obowiązywały cotygodniowe składki oraz zbieranie jałmużny na rzecz potrzebujących ${ }^{20}$.

Od XV w. dobroczynność pozostała nadal w rękach duchowieństwa, ale do głosu doszły także władze państwowe, które wymagały, aby fundacje dobroczynne były zatwierdzane przez stany Rzeczypospolitej. Generalnie państwo popierało zakładanie instytucji dobroczynnych i zwalniało je od podatków, ale rozpoczęło kontrolę i nadzór nad działalnością charytatywną duchowieństwa. W 1669 r. Sejm uchwalił, że „każde przejście dóbr ziemskich na korzyść duchowieństwa jest nieważne, jeżeli było uczynione bez zezwolenia stanów Rzeczypospolitej"21. Poza tym, pełnienie dobroczynności państwo pozostawiło także staraniom osób prywatnych, bractwom i korporacjom.

Kolejnym wydarzeniem w historii opieki nad sierotami był okresowy upadek akcji charytatywnej Kościoła. Przyczyną tego była reformacja. Likwidacji uległo wówczas wiele szpitali oraz funduszy dla ubogich ${ }^{22}$. Jednak już pod koniec XVI w. władza Kościoła nad szpitalnictwem stała się niepodzielna. Wynikało to z przyjęcia uchwały soboru trydenckiego na synodzie piotrkowskim w 1577 r. Uchwały synodów biskupich dodatkowo umocniły prawa duchowieństwa do kierowania szpitalnictwem, nawet świeckim. Administracje szpitalne zostały zobowiązane do corocznego składania sprawozdań biskupom lub ich przedstawicielom ${ }^{23}$.

Od XVI w. szpitale i przytułki zakładane były przez proboszczów, właścicieli wsi, gromady, a nawet przez włościan. Liczby szpitali w Polsce przedrozbiorowej nie da się dokładnie określić. Jedne były likwidowane, inne powstawały, liczba ich stale się zmieniała $^{24}$.

\footnotetext{
16 Ibidem, s. 32-33.

${ }^{17}$ K. Koralewski, Opieka społeczna w Stolicy Niepodległej Polski (1918-1928), Warszawa 1929, s. $13-15$.

${ }^{18}$ H. Zaremska, Bractwa w średniowiecznym Krakowie. Studium form społecznego życia religijnego, Wrocław - Warszawa - Kraków 1977, s. 44-49.

19 Ibidem, s. 15.

${ }^{20}$ K. Koralewski, op. cit., s. 15-16.

21 Ibidem, s. 15.

${ }^{22}$ K. Górski, op. cit., s. 216-217.

23 J. Tazbir, Historia Kościoła Katolickiego w Polsce (1460-1795), Warszawa 1966, s. 39 i 43.

${ }^{24}$ Z. Góralski, op. cit., s. 29.
} 
Przykładem stosowania różnych form opieki nad sierotami, dziećmi porzuconymi i biednymi mogą być działania podjęte w Gdańsku, Toruniu i Warszawie. Uwidoczniło się w nich dążenie do wyodrębniania z ogółu działań dobroczynnych opieki nad dzieckiem i tworzenie zakładów wyłącznie dla dzieci.

W Gdańsku w 1525 r. Rada Miasta zarządziła oddzielenie w zakładach dobroczynnych dzieci od dorosłych. W 1541 r. doszło do odizolowania dzieci ze szpitala św. Elżbiety i utworzenia domu, początkowo przewidzianego dla czterdziestu wychowanków. Miejsce znalazły tam dzieci z nieprawego łoża, podrzutki oraz tzw. pauperowie (dzieci biedoty). W latach 1720-1729 przyjęto 309 dzieci, 103 ślubnych i 206 nieślubnych, w tym 37 podrzutków ${ }^{25}$.

W 1699 r. wzniesiono w Gdańsku przytułek dla biednych, w którym właściwie mieścił się drugi sierociniec. Umieszczono w nim dzieci wałęsające się i proszące o jałmużnę. W 1730 r. było w zakładzie 185 dzieci mających rodziców i 301 sierot $^{26}$. W obu gdańskich placówkach najzdolniejszych wychowanków przełożeni urzędów dobroczynnych kierowali nawet na studia zagraniczne ${ }^{27}$.

Inaczej problem sieroctwa rozwiązywano w Toruniu. Nie otwierano tam instytucji opiekuńczo-wychowawczych. Wspólnota miejska podporządkowała sobie opiekę nad sierotami, wypierając rodzinę i przyjaciół zmarłych rodziców. Ich wychowania nie powierzano jednak przypadkowym osobom. Utworzono urząd sierocy, który zatwierdzał opiekunów wyznaczonych wcześniej przez rodziców w testamencie, jeśli zaś nie byli oni imiennie wskazani, wyznaczano ich z urzędu. W czasie trwania opieki urząd sierocy kontrolował pracę zastępczych rodziców, podejmował ważniejsze decyzje (jeśli były takie potrzebne) dotyczące przyszłości dziecka. Do zadań urzędów należało też kontrolowanie wszelkich rachunków wynikających z gospodarowania dobrami wychowanka oraz przeprowadzanie ewentualnych procesów sądowych w sprawach związanych z opieką ${ }^{28}$.

W Warszawie opiekę nad dziećmi porzuconymi pełnił Szpital Świętego Ducha ekstra muros ufundowany w XIV w. Natomiast w latach dwudziestych XVII w. w celu opieki nad sierotami i podrzutkami został zbudowany szpital - przytułek św. Benona, administrowany przez bractwo pod tym samym wezwaniem. Funkcjonował on do czasu potopu szwedzkiego, kiedy to uległ spaleniu ${ }^{29}$.

W latach 1732-1736 w Warszawie został założony szpital dla podrzutków pod wezwaniem Dzieciątka Jezus. Jego założycielem był Francuz ks. G. Baudouin. System opieki nad podrzutkami był analogiczny do wypracowanego w szpitalu Świętego Ducha. Funkcje opiekuńczo-wychowawcze pełniły tam szarytki. O potrzebie istnienia tej pla-

${ }^{25}$ Z. Kropidłowski, Organizacja dziet miłosierdzia chrześcijańskiego $w$ Gdańsku w XVI-XVIII w., w: Charitas. Miłosierdzie i opieka społeczna w ideologii, normach postępowania i praktyce społeczności wyznaniowych $w$ Rzeczypospolitej XVI-XVIII w., red. U. Augustyniak, A. Karpiński, Wyd. Naukowe Semper, Warszawa 1999, s. 139-160.

${ }_{26}$ Z. Kropidłowski, Formy opieki nad ubogimi w Gdańsku od XVI-XVIII wieku, Gdańsk 1992, s. 115.

27 Z. Kropidłowski, Organizacja dzieł..., s. 159.

${ }^{28}$ G. Mazek, Opieka nad sierotami w Toruniu, w: Charitas..., s. 131-138.

${ }^{29}$ M. Surdacki, op. cit., s. 160-161. 
cówki świadczy fakt, że w pierwszym roku funkcjonowania do szpitala przyjęto 45 dzieci, a rok później przebywało w nim już 241 podopiecznych ${ }^{30}$.

W 1736 r. biskup poznański S. J. Hozjusz zatwierdził Szpital i nadał przywilej zbierania ofiar, przeznaczonych na jego powstanie. Kasztelanowa Urszula z Bielińskich Czerwińska, aktem z dnia 28 lutego 1738 r. zapisała swoje dobra na rzecz tej instytucji. Dnia 24 czerwca 1754 r. ks. G. Baudouin położył kamień węgielny pod budowę nowego gmachu szpitala, który w rok później został wykończony ${ }^{31}$. W 1746 r. król August III przyznał wychowankom przywilej, ,prawnego, legalnego urodzenia”, a w 1758 r. Szpital Dzieciątka Jezus został podniesiony do rangi szpitala generalnego. Rozszerzony też został zakres jego działania opiekuńczego ${ }^{32}$. Szpital miał się zajmować nie tylko sierotami, ale też chorymi (zarówno fizycznie, jak i psychicznie), ubogimi, żebrakami, kalekami i włóczęgami.

Po 1768 r. władzę hierarchiczną nad szpitalami w Warszawie przejęły państwowe i samorządowe organa opieki społecznej. Od tego czasu Szpital Generalny Dzieciątka Jezus uległ stopniowemu, wyraźnemu podziałowi na dwa różne zakłady: jeden o charakterze leczniczym, drugi o charakterze opiekuńczo-wychowawczym ${ }^{33}$. W XIX w. Rada Miejska Dobroczynności Publicznej postanowiła wybudowanie nowego Szpitala Generalnego, co sfinalizowano w 1901 r. Wtedy również przeprowadzono wychowanków do nowego budynku.

$\mathrm{Na}$ terenie Rzeczypospolitej sierotami zajmował się także Kościół prawosławny. Na synodzie biskupów w 1594 r. postanowiono przeznaczyć część dochodów władyków ruskich na utworzenie przytułków i szkół, zobowiązano również monastery i bractwa cerkiewne do prowadzenia szpitali i szkół ${ }^{34}$. Zjawisko łączenia przez monastery funkcji oświatowej i charytatywnej występowało w większych ośrodkach zakonnych.

Działalnością na rzecz sierot zajmowały się również efektywnie bractwa cerkiewne, które zakładały i utrzymywały szpitale. Środki na działalność charytatywną pochodziły, podobnie jak w przypadku bractw religii rzymskokatolickiej, ze składek jego członków, darowizn oraz z zysku z posiadanych domów i nieruchomości przejętych na podstawie testamentów.

Szpitale i przytułki prowadziło też duchowieństwo świeckie. Szpitale stanowiły swego rodzaju agendy parafialne. Największy rozwój szpitalnictwa prowadzonego przez duchowieństwo prawosławne przypada na XVI i XVII stulecie.

W drugiej połowie XVII w. liczba szpitali i przytułków prowadzonych przez bractwa i monastery zmalała. Powodem tego było ubożenie społeczeństwa, zmniejszanie się liczby wyznawców prawosławia na terenie Rzeczypospolitej i osłabienie pozycji Cerkwi

\footnotetext{
${ }^{30}$ Ibidem, s. 161-162.

31 J. Lubczyński, Cele i zadania Domu ks. Boduena [sic!] 1736-1936, dodatek do „Opiekun Społeczny” XII 1936, Warszawa 1936, s. 5-8.

${ }^{32}$ M. Surdacki, op. cit., s. 163.

33 J. Lubczyński, op. cit., s. 8.

${ }^{34}$ A. Mironowicz, Działalność charytatywna w Kościele Prawosławnym na terenie Rzeczypospolitej w XVI-XVIII wieku, w: Charitas..., s. 79.
} 
prawosławnej. Pomimo tych trudnych okoliczności, jeszcze w XVIII w. monastery i bractwa prowadziły swą działalność (w ograniczonym zakresie) na rzecz sierot ${ }^{35}$.

Stosunkowo niewiele wiadomo na temat opieki nad sierotami w środowisku żydowskim. Może ją egzemplifikować działalność gminy żydowskiej w Swarzędzu ${ }^{36}$. Za wypełnianie obowiązku dobroczynności, także względem sierot, odpowiedzialne były władze gminy. Urzędnicy, którzy bezpośrednio zajmowali się tą działalnością, uchodzili za jednych z ważniejszych w składzie władz gminnych. Istniała też kasa dobroczynności. Początkowo gabaje gminy zajmowali się wszystkimi rodzajami działań dobroczynnych, później jednak niektóre ich zadania przejmowały bractwa ${ }^{37}$.

Kościół protestancki na terenie dawnej Rzeczypospolitej również prowadził działalność opiekuńczo-wychowawczą względem sierot. Tutaj, ,jak w całym europejskim chrześcijaństwie - właśnie parafie były instytucjami powołanymi do wypełniania funkcji opiekuńczych"38. Uważano, że dobrze zorganizowana parafia ewangelicka powinna posiadać obok świątyni i szkoły, także dom opieki (szpital). Sieroty lokowano w szpitalach zborowych wraz z wdowami, ośrodki te nazywano przytułkiem dla wdów, bądź domem sierockim. Nadzór nad tymi instytucjami pełnił pastor ${ }^{39}$. Opiekuńczą działalność Kościoła ewangelickiego finansowała jego świecka, szlachecka elita ${ }^{40}$. Motywacją do składanych ofiar była idea miłosierdzia - cnota właściwa chrześcijanom.

$\mathrm{Z}$ zachowanych do dziś informacji dotyczących wyglądu jednego z ewangelickich, osiemnastowiecznych szpitali wynika, że był to budynek drewniany, kryty dranicami ${ }^{41}$, mieszczący się przed bramą prowadzącą na teren kościoła. W szpitalu były dwie izby, a w nich: piece kaflowe, ławy, szafy, oszklone okna. Późniejszy opis domu opieki, pochodzący z 1794 r. wskazuje na ulepszenie szpitala. Posiadał on osiem izb, cztery piece w głównym korytarzu, osobną kuchnię, piekarnię z dwoma glinianymi piecami. Pokoje były zamykane na zamek, a w nich: podłogi z tarcic ${ }^{42}$, stoły na krzyżaku, małe stoliki z szufladami, ławy i oszklone okna ${ }^{43}$. Podobnie wyglądały wszystkie inne szpitale ewangelickie.

Reasumując, można stwierdzić, że w omówionym okresie na ziemiach polskich opieka nad dzieckiem osieroconym lub porzuconym miała charakter środowiskowy, wynikający z woluntarystycznych, filantropijno-charytatywnych działań podejmowanych najwcześniej i w najszerszym zakresie przez Kościół. Wyodrębnienie ze szpitali i przytułków

\footnotetext{
35 Ibidem, s. 79-86.

${ }^{36}$ A. Michałowska, Dobroczynność i bractwa dobroczynności (Chewra Kadisza) w gminie żydowskiej w Swarzędzu w XVIII wieku, w: Charitas..., s. 107.

${ }^{37}$ Ibidem, s. 107-108.

${ }^{38}$ W. Kriegseisen, Miłosierdzie czy opieka społeczna ? Działalność opiekuńcza w Jednocie Ewangelicko-Reformowanej Wielkiego Księstwa Litewskiego w XVIII wieku, w: Charitas..., s. 116.

39 Ibidem, s. $123-125$.

40 Ibidem, s. 127.

${ }^{41}$ Dranica - cienka, wąska deska łupana z pnia drzewa iglastego, używana w budownictwie zwykle do krycia dachów.

42 Tarcica - materiał drzewny otrzymany przez pocięcie okrąglaków równolegle do ich osi podłużnych; jedna z desek otrzymanych w ten sposób.

${ }^{43}$ W. Kriegseisen, Miłosierdzie..., s. 119-120.
} 
oddziałów dla dzieci, a zwłaszcza zorganizowany w Warszawie z inicjatywy Ks. G. Baudouina zakład opiekuńczy dla dzieci, można uznać za prototypowe działania w zakresie zakładowej opieki całkowitej nad dzieckiem osieroconym.

W okresie zaborów zaś sytuacja zakładów opiekuńczych dla sierot uległa zróżnicowaniu $^{44}$, gdyż zależała od polityki zaborców i aktywności obywatelskiej. Wyznaczały więc ją z jednej strony interesy państw zaborczych, z drugiej ukształtowana tradycja. W każdym z zaborów następowały jednak okresy liberalizacji, co umożliwiało przynajmniej częściowe realizowanie własnych koncepcji. Były to przede wszystkim działania filantropijne i dobroczynne grup religijnych, stowarzyszeń i osób prywatnych.

W XIX w., po zakończeniu ateizmu z okresu rewolucji francuskiej, rozpoczęty w Europie okres odrodzenia religijnego, który zaowocował powołaniem do życia wielu nowych zakonów zajmujących się wychowaniem, miał swoiste odzwierciedlenie także na ziemiach polskich. Mimo że państwa zaborcze likwidowały istniejące wcześniej zakony ${ }^{45}$, to od połowy XIX w. miał miejsce ,,żywiołowy proces rozwoju nowych zgromadzeń zakonnych - rodzimych i przeszczepionych z zachodu"46.

Wśród nowych wspólnot, z inicjatywy o. Honorata Koźmińskiego powstało 18 tajnych (bezhabitowych) zgromadzeń żeńskich, z których to opieką i wychowaniem sierot zajmowały się następujące $\mathrm{z}$ nich:

- Zgromadzenie Sióstr Felicjanek, działające w środowiskach wiejskich Podlasia i Lubelskiego, a po powstaniu styczniowym - w Galicji,

- Zgromadzenie Sióstr Córek Najczystszego Serca Maryi, które oprócz prowadzenia sierocińców niosły także pomoc zesłańcom na Syberii; w domach prowadzonych przez to zgromadzenie wychowało się i wykształciło tysiące dzieci.

Ponadto opieką nad sierotami zajmowały się również:

- Zgromadzenia Sióstr Opatrzności Bożej prowadzące dom dla sierot zwany Zakładem św. Teresy (koło Rzeszowa); sierocińce oraz zakłady wychowawcze w Galicji, na Górnym Śląsku i Wołyniu,

- Siostry Franciszkanki Świętej Rodziny Maryi, których działalność rozwijała się nie tylko na ziemiach polskich, ale także wśród emigracji polskiej,

\footnotetext{
${ }^{44}$ Granice między zaborami do 1815 r. ulegały zmianom. Po rozbiorach ziemie wschodnie Rzeczypospolitej (do Niemna) zostały wcielone do Rosji. Ziemie Polski centralnej (z Warszawą i Poznaniem) do 1806 r. należały do Prus, w latach 1807-1815 stanowiły Księstwo Warszawskie, a od 1815 r. (bez Krakowa i Poznania) Królestwo Polskie (tzw. Kongresowe) połączone unią personalną z Rosją. Królestwo Polskie formalnie miało pewną odrębność, która jednak ograniczona została po powstaniu listopadowym, a zlikwidowana po powstaniu styczniowym. Mniejsze zmiany terytorialne były w zaborze pruskim. Wielkie Księstwo Poznańskie stale należało do Prus, poza okresem wojen napoleońskich. Natomiast Śląsk i Pomorze wchodziły w skład Prus już od XVIII w. W Galicji bardziej skomplikowane losy dotyczyły jej części Zachodniej (z Krakowem) niż Wschodniej (ze Lwowem). Po 1815 r. część Galicji Zachodniej tworzyło tzw. Rzeczpospolitą Krakowską, którą w 1848 r. wcielono do Austrii i poddano germanizacji. Możliwości repolonizacji nastąpiły dopiero po autonomii Galicji w 1866 r.

45 W Królestwie Polskim po powstaniu listopadowym zlikwidowano kilkaset domów zakonnych, a po powstaniu styczniowym z 167 klasztorów w 1904 r. pozostało zaledwie 15. W zaborze pruskim kasacji uległo również wiele zakonów. W zaborze austriackim liczne kasaty zakonów miały miejsce za czasów Józefa II.

46 S. J. Możdżeń, Historia wychowania 1795-1918, Wyd. Stachurski, Kielce 2000, s. 39.
} 
- Zgromadzenie Służebnic Najświętszego Serca Jezusowego, które oprócz pracy opiekuńczej prowadziło dwie szkoły gospodarcze dla dziewcząt ${ }^{47}$,

- Zgromadzenie Sióstr Służek, prowadzące m.in. w Płungianach (w guberni kowieńskiej) schronisko dla podrzutków i osieroconych niemowląt ${ }^{48}$.

Na przełomie XIX/XX w. szczególnie zaangażowaną działalność opiekuńczo-wychowawczą wobec sierot prowadził salezjanin ks. Bronisław Markiewicz. Założył on w 1892 r. w Miejscu Piastowym koło Krosna zakład dla sierot, w którym w początkowym okresie działalności przebywało 30 wychowanków. Osobowość i idea pracy opiekuńczo-wychowawczej ks. Markiewicza pociągnęła i skupiła wokół niego młodzież dorosłą, która pragnęła być jego pomocnikami, a w przyszłości kapłanami. Jednak zaledwie po kilku latach działalności zakładu przełożeni ze Zgromadzenia Salezjańskiego w Turynie zaczęli ograniczać liczbę wychowanków i utrudniać pracę wychowawczą zakładu. W tej sytuacji ks. Markiewicz na własną prośbę został zwolniony ze Zgromadzenia Salezjańskiego i utworzył świeckie Towarzystwo „Powściągliwość i Praca”, którego statut opierał się na wskazówkach św. Jana Bosko. Działalność Towarzystwa zaowocowała rozbudową obiektów w Miejscu Piastowym, co umożliwiło zamieszkanie tam przeszło 240 wychowanków opuszczonych lub wywodzących się z rodzin ubogich. Sukcesem ks. Markiewicza było także i to, że po dziesięciu latach działalności zakładu kilkunastu wychowanków studiowało na uniwersytetach w kraju i za granicą. Poza tym wychowankowie ks. Markiewicza prowadzili zakłady w Warszawie i w Wilnie oraz zorganizowali dwa zakłady w Galicji ${ }^{49}$.

Z innych zgromadzeń prowadzących przytułki dla dzieci lub sierocińce wymienić można: Zgromadzenie Opatrzności, Józefitki, Służebnice Serca Jezusowego, Siostry Miłosierdzia. Spośród wymienionych szczególnie znanymi w opiece nad podrzutkami były Siostry Miłosierdzia ${ }^{50}$.

Mimo odmiennych warunków i okoliczności, w jakich prowadziły działalność opiekuńczo-wychowawczą zakony, ideał wychowawczy stanowił model dobrego chrześcijanina katolika i Polaka o silnym charakterze.

W okresie zaborów bardzo istotną rolę w opiece nad sierotami spełniły towarzystwa dobroczynne i wszelkiego rodzaju stowarzyszenia.

W Galicji na początku XIX w. powstało Polskie Towarzystwo Dobroczynności, które w 1830 r. utworzyło sierociniec. W miarę upływu czasu (w połowie XIX w.) temu Towarzystwu podlegały już 3 ochronki, w których przebywało 233 dzieci. W 1911 r. na terenie Galicji istniały 52 stowarzyszenia dobroczynne, które zajmowały się dziećmi i młodzieżą. Generalnie, zakładów dobroczynnych w tym zaborze było wówczas 341, z czego 24 to sierocińce, a pozostałych 265 - to ochronki i schroniska ${ }^{51}$.

\footnotetext{
47 Ibidem, s. 39-42.

${ }^{48}$ T. Wróblewski, Dobroczynność oświatowo-wychowawcza Zgromadzenia Sióstr Stużek, w: W dialogu z przeszłością. Księga poświęcona Profesorowi Janowi Hellwigowi, red. W. Jamrożek, D. Żołądź-Strzelczyk, Poznań 2002, s. 214.

49 S. J. Możdżeń, op. cit., s. 42-43.

${ }^{50}$ M. Surdacki, op. cit., s. 163.

${ }^{51}$ Cz. Kępski, Idea miłosierdzia a dobroczynność i opieka, Wyd. UMCS, Lublin 2002, s. 107-111.
} 
Największą liczbą towarzystw dobroczynnych odznaczało się Królestwo Polskie. W latach największego ucisku narodowego działały tam: Wileńskie Towarzystwo Dobroczynności, Warszawskie Towarzystwo Dobroczynności, Lubelskie Towarzystwo Dobroczynności, Żydowskie Towarzystwo Dobroczynności, Rosyjskie Towarzystwo Dobroczynności Królestwa Polskiego ${ }^{52}$, Towarzystwo Dobroczynności w Radomiu, Kieleckie Towarzystwo Dobroczynności, Towarzystwo Wspierania Ubogich w Siedlcach, Kaliskie Towarzystwo Dobroczynności, Pabianickie Chrześcijańskie Towarzystwo Dobroczynności. ${ }^{53}$ Jednym $z$ naczelnych celów towarzystw było zapewnienie opieki sierotom.

Towarzystwa Dobroczynności Królestwa Polskiego podlegały Radzie Głównej Opiekuńczej, która w 1859 r. uzyskała prawo kontroli nad wszystkimi zakładami opiekuńczymi. Ze sprawozdania Rady wynika, że w zaborze rosyjskim w 1859 r. istniały 4 zakłady opiekuńczowychowawcze, w których przebywało 557 dzieci. Były to: Dom Sierot Warszawskiego Towarzystwa Dobroczynności zamieszkiwany przez 170 dzieci; Dom Sierot Lubelskiego Towarzystwa Dobroczynności z 14 wychowankami; Instytut Św. Kazimierza posiadający 110 podopiecznych; Instytut Głuchoniemych i Ociemniałych, gdzie opiekę znalazło 126 sierot; szpitale, w których przebywało 137 podopiecznych. Ponadto w 14 ochronkach działających z ramienia towarzystw, przebywało 709 dzieci, z czego: w 8 ochronkach Warszawskiego Towarzystwa Dobroczynności - 500 dzieci; w 2 ochronkach Lubelskiego Towarzystwa Dobroczynności - 75. Ochrony działały też w Kaliszu, Białej, Płocku i Kielcach ${ }^{54}$.

Tragiczny los dotknął polskie sieroty, dzieci bezdomne, bądź odebrane rodzicom, które na mocy polecenia Mikołaja I w końcu 1831 r. zostały deportowane do Rosji. Była to jedna z represyjnych akcji władz carskich wobec społeczeństwa polskiego. Dokładna liczba dzieci polskich zesłanych do Rosji nie jest znana, lecz można przypuszczać, że było ich około 2000. Większość stanowili chłopcy, zsyłani przede wszystkich do oddziałów kantonistów (rezerwistów). Bliżej nieznana jest natomiast deportacja dzieci polskich z ziem wschodnich byłej Rzeczypospolitej (Litwa, Wołyń, Podole) ${ }^{55}$.

Innym przykładem represji po powstaniu listopadowym było odsunięcie od pracy pedagogicznej Stanisława Jachowicza z powodu działalności w Towarzystwie Patriotycznym i założenia Towarzystwa Wychowania Dzieci po Poległych Rycerzach. Mimo to Stanisław Jachowicz nadal bezpłatnie angażował się w pracy powstałego z jego inicjatywy sierocińca, a także udzielał bezpłatnych lekcji w ochronkach Warszawskiego Towarzystwa Dobroczynności ${ }^{56}$.

W drugiej połowie XIX w. na terenie Królestwa Polskiego działało też Żydowskie Towarzystwo Dobroczynności i Rosyjskie Towarzystwo Dobroczynności. Żydowskie Towarzystwo Dobroczynności ${ }^{57}$ przybierało różne formy dobroczynności, zajmowało się chorymi, biednymi, młodzieżą studiującą i sierotami.

\footnotetext{
52 Cz. Kępski, Towarzystwa Dobroczynności, s. 132-219.

${ }^{53}$ Cz. Kępski, Idea miłosierdzia ..., s. 96-97.

54 Ibidem, s. 64.

55 A. Winiarz, Wywózki dzieci polskich do Rosji po powstaniu listopadowym, w: Dziecko w rodzinie..., s. 232-237.

${ }^{56}$ Historia wychowania, red. Ł. Kurdybacha, Warszawa 1967, s. 200.

${ }^{57}$ Cz. Kępski, Towarzystwa Dobroczynności...., s. 206-213.
} 
Na przełomie XIX i XX w. rozgłos zdobyła pomoc świadczona przez Towarzystwo „Pomocy” dla Sierot. Charakterystyczne było wypracowanie interesującego systemu opieki nad dziećmi, polegającego na łączeniu różnych form tejże opieki. Zasługą tego Towarzystwa było założenie w Warszawie przy ulicy Krochmalnej 92 sierocińca pod nazwą „Nasz Dom”, którego kierownikiem był Janusz Korczak (Henryk Goldszmit).

W drugiej połowie XIX i na początku XX w. działalność prowadziło także, wcześniej wspomniane Rosyjskie Towarzystwo Dobroczynności ${ }^{58}$, którego siedziba znajdowała się w Warszawie, a oddziały w miastach gubernialnych: Kielcach, Kaliszu, Piotrkowie i Radomiu. Ich praca polegała głównie na prowadzeniu przytułku dla dzieci i wypłacaniu zapomóg dorosłym. Dzięki poparciu władz miały dobrą sytuację finansową, a w konsekwencji - bytową. Bliżej znana jest praca opiekuńczo-wychowawcza z sierotami, którą prowadziło Rosyjskie Towarzystwo Dobroczynności w Lublinie. W 1868 r. uruchomiło ono w tym mieście przytułek dla wdów i sierot wyznania prawosławnego. Większość jednak dzieci przebywających w przytułku pochodziło z małżeństw mieszanych pod względem religijnym i narodowościowym. Można przypuszczać, że w ten sposób zamierzano uchronić wychowanków ,przed katolizacją i polonizacją, gdyż dziecko w ochronce wychowywano w duchu rosyjskim"s9.

Obok zakładów powstałych dzięki towarzystwom dobroczynnym i działających w myśl przyjętych (przez te towarzystwa) zasad, istniały również i takie, które legitymowały się inną przynależnością i sobie właściwym stylem pracy. I tak np. w Warszawie schronienie dla sierot nadal zapewniał dom podrzutków - Szpital Dzieciątka Jezus, założony przez ks. Gabriela Baudoina i prowadzony głównie przez osoby duchowne. Opiekowano się tam 2775 dziećmi, z tym że bezpośrednio w szpitalu przebywało 100 niemowląt i 75 dzieci starszych, natomiast 2600 dzieci oddano na wychowanie (za opłatą) kobietom wiejskim.

W Krakowie funkcjonowały (z przeznaczeniem dla sierot) instytucje opiekuńcze mające wielowiekową tradycję - sięgającą czasów średniowiecza, odrodzenia i kontrreformacji. Za wzorcową placówkę uznawano istniejący od wieków Szpital Świętego Ducha. Natomiast na początku XIX powstał największy wówczas Szpital Świętego Łazarza, posiadający kilka oddziałów: dla niemowląt, dzieci i dorosłych. Rocznie przyjmowano tam około 300 dzieci, z czego jednorazowo przebywało przy mamkach około 24 niemowląt i około 120 dzieci starszych.

We Lwowie pewna liczba dzieci znalazła schronienie w klasztorze Sióstr Miłosierdzia, a od 1859 r. sieroty przebywać mogły także w zakładzie, ufundowanym przez władze miejskie.

Problemy dotyczące opieki nad dzieckiem opuszczonym i osieroconym znajdowały się także w kręgu zainteresowań galicyjskiej socjalnej demokracji. Dotyczyły one rozwoju opieki zakładowej (domów sierot, schronisk dla dzieci bezdomnych). Żądania w tym zakresie „stawiano zwłaszcza przez gminami i stanowiły one fragment szerszego programu gminnego socjalnej demokracji”, ${ }^{\prime 60}$.

\footnotetext{
58 Ibidem, s. 213-219.

${ }^{59}$ K. Latawiec, Działalność przytułku Rosyjskiego Towarzystwa Dobroczynności w Lublinie w latach 1868-1915, w: Dziecko w rodzinie..., s. 171-172.

${ }^{60}$ W. Jamrożek, Opieka nad dzieckiem $w$ opinii $i$ poczynaniach galicyjskiej socjalnej demokracji, w: Dziecko w rodzinie..., s. 246.
} 
Pomimo tak licznie istniejących różnego typu zakładów, domów dla sierot i ochronek zarówno w zniewolonej Polsce, jak i całej Europie istniała tendencja do umieszczania sierot w rodzinach zastępczych. Powodem tego była wysoka umieralność dzieci w tychże placówkach. Przypuszczano nawet, że podopieczni są umyślnie uśmiercani. Inni wyjaśniali zgony faktem zgromadzenia większej liczby dzieci w jednym budynku i zbiorowym żywieniem, w końcu - chorobą sierocą ${ }^{61}$.

W umieszczeniu dziecka w rodzinie zastępczej pomagały Gminne Rady Sieroce. Powoływano je w Galicji (na początku XIX w.) i dosyć licznie w zaborze pruskim.

W zaborze pruskim członkowie Rady wyszukiwali kandydatów na opiekunów dla sierot, oraz kontrolowali ich pracę. Zastosowano tam opiekę zawodową, za którą osoby wychowujące otrzymywały wynagrodzenie. Generalnie bowiem starano się zapewnić wychowanie w kręgu rodzinnym. Porzucane noworodki umieszczano więc w rodzinach zastępczych, którym wypłacano regularnie pewną kwotę pieniędzy z kas gminnych lub ze środków organizacji społecznej ${ }^{62}$. Dzięki takim rozwiązaniom zakładów opieki całkowitej nie było wiele (np. w 1913 r. było ich 18$)^{63}$.

Stwierdzić należy, że zakłady dla sierot (we wszystkich zaborach) posiadały jeszcze w początkach XX w. organizację dawną, odbiegającą od najnowszych, a wypróbowanych za granicami kraju ${ }^{64}$.

W każdym z zaborów działania opiekuńczo-wychowawcze nad sierotami wynikały z przyjętego ustawodawstwa. W zaborze austriackim ${ }^{65}$ obowiązkiem sprawowania opieki nad sierotami objęte były gminy, określała to ustawa z dnia 3 XII 1863 r. W zaborze pruskim, obowiązek sprawowania opieki trwałej przez gminy określała ustawa z czerwca 1870 r. ${ }^{66}$ Nadmienić należy, że ustawodawstwo w Prusach było bardzo podobne do austriackiego, różnicę stanowiła właściwie skuteczność działania - bardziej efektywna w zaborze pruskim.

Nieco inaczej problematykę sieroctwa ujmowały regulacje prawne w zaborze rosyjskim. Tam na mocy postanowienia z 1817 r. opieka publiczna opierała się na dobrej woli społeczeństwa. Dopiero na podstawie prawa z 1870 r. zaistniały gubernialne i miejskie rady dobroczynności publicznej, sprawujące nadzór nad zakładami i towarzystwami dobroczynnymi ${ }^{67}$.

Pod koniec XIX i na początku XX w. na ziemiach polskich w środowiskach społecznych, zwłaszcza wśród działaczy społeczno-oświatowych, wzrastało zainteresowanie

${ }^{61}$ H. Fierek, M. Fierek-Kaźmierowska, Dzieje opieki nad dzieckiem, Słupsk 1991, s. 85-86.

${ }^{62} \mathrm{Cz}$. Kępski, Idea miłosierdzia..., s. 111-112.

${ }^{63}$ S. Wilczyński, Opieka społeczna nad niemowlęciem, dzieckiem i młodzieża w Wielkopolsce, Poznań 1927, s. 6.

${ }^{64}$ A. Ostrowski, Dziecko w opiece publicznej, Wyd. Nakładem Lwowskiego Towarzystwa Walki z Gruźlicą, Lwów 1929, s. 135.

${ }^{65}$ M. Kuzańska-Obrączkowa, Koncepcje wychowawcze Robotniczego Towarzystwa Przyjaciół Dzieci 1918-1939. Analiza założeń i funkcjonowania placówek, w: Monografie pedagogiczne, red. B. Suchodolski, T. XVIII, Wrocław - Warszawa - Kraków 1966, s. 16.

${ }^{66}$ M. Kuzańska-Obrączkowa, op. cit., s.16.

${ }^{67}$ Ibidem, s. 16. 
sprawami opieki nad dzieckiem ${ }^{68}$. Dostrzegano konieczność „,wyjścia poza dotychczasowy dominujący krąg działalności charytatywno-filantropijnej w zakresie opieki nad dzieckiem na rzecz działań opiekuńczych, wspartych na określonych podstawach prawnych i publicznym charakterze, pojmowanych w kategoriach służby społecznej”"69.

Problematyka opieki nad sierotami była m.in. tematem obrad na II Kongresie Pedagogicznym zorganizowanym w 1909 r. we Lwowie, na którym K. Jeżewski przedstawił oryginalną koncepcję gniazd sierocych. Celem ich było stworzenie odpowiednich warunków wychowawczych dla sierot i przygotowanie ich do życia, oraz dostarczenie stosownych ,wzorów życia na wsi”. Realizacji tej formy opieki nad sierotami patronować miało Towarzystwo Gniazd Sierocych, które tworzyłoby wzorowe formy przemysłowo-rolne, oddane w użytkowanie odpowiednio dobranej rodzinie. W rodzinie tej przebywałoby dziesięcioro sierot $\mathrm{w}$ różnym wieku, wychowywanych „,w pracy i miłości zarówno jak własne dzieci gospodarzy" "70.

W okresie I wojny światowej problem sieroctwa przybrał inny wymiar, tzw. sieroctwa wojennego, to jest zjawiska „osamotnienia dzieci i młodzieży, bezpośrednio lub pośrednio spowodowanego działaniami wojennymi" "71. Wśród sierot wojennych wyróżnić było można dzieci tułacze, dzieci bezdomne i dzieci - ofiary eskterminacji. Szczególną kategorią sierot wojennych były „dzieci syberyjskie”. Oblicza się, że w okresie od I wojny światowej do 1922 r. na terenach Syberii i Mandżurii przebywało kilkanaście tysięcy Polaków ${ }^{72}$, z czego duży procent stanowiły dzieci ${ }^{73}$. Po zakończeniu wojny rozpoczęto zorganizowaną akcję deportacji tych dzieci do kraju.

\footnotetext{
${ }^{68}$ Wpływ na wzrost tego zainteresowania miał rozwój nauk biologicznych, medycznych, psychologii (zwłaszcza pedologii), recepcja idei ,nowego wychowania” stwarzające podstawy do poznania praw rozwojowych dzieci, ich specyficznych potrzeb i środków zaspokajania. Dostrzegano też negatywne skutki rozwijającego się kapitalizmu i uprzemysłowienia, które wyznaczały nowe potrzeby opieki nad dzieckiem. W. Jamrożek, Problematyka opieki nad dzieckiem na kongresach i zjazdach pedagogicznych w Polsce do 1939 roku, w: Kongresy i zjazdy pedagogiczne w Polsce w XX wieku, red. A. Kicowska, Torun 2001, s. 121.

${ }^{69}$ Ibidem, s. 121.

${ }^{70}$ Ibidem, s. 123.

71 W. Theiss, Dzieci syberyjskie. Z badań nad sieroctwem wojennym, „Problemy Opiekuńczo-Wychowawcze" 1991, nr 5, s. 237.

72 Ibidem, s. 237.

${ }^{73}$ W listopadzie 1922 r. Komitet Ratunkowy podjął starania wywiezienia ich z tych terenów. Udało się uzyskać zgodę Japońskiego Ministerstwa Spraw Zagranicznych oraz Japońskiego Czerwonego Krzyża na przewiezienie dzieci do Japonii. W związku z tym ,pozbierano” je z rosyjskich i chińskich przytułków, koszar, ochron i wywieziono. Mali repatrianci znaleźli opiekę i dobre warunki życia w sierocińcu towarzystwa buddyjskiego Fukudenkai. Stamtąd przewieziono je do USA, gdzie zaopiekowały się nimi polonijne związki i stowarzyszenia kościelne. Rolę głównego gospodarza pełnił Wydział Narodowy Polski w Chicago, któremu udostępniono sierocińce i szkoły w kilku miejscowościach pod Chicago i Pittsburgiem. Kolejny, a zarazem ostatni etap podróży „,dzieci syberyjskich” wiódł już do kraju. Pod koniec stycznia 1922 r. z Nowego Jorku wypłynął statek wiozący 310 repatriowanych dzieci. Dobrnęli do Bremen, a stąd pociągiem udano się do Poznania. Na stacji w Zbąszynie dzieci odebrali przedstawiciele Towarzystwa Dobroczynnego „Caritas”, następnie umieszczono je w zakładach opiekuńczych w Mielżynie i Broniszewicach.
} 
